\section{Gravenstein and Jonathan Apples produced with Gibberellic Acid}

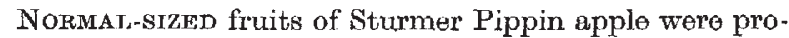
duced by Davison ${ }^{1}$ using 1 per cont gibberellic acid (GA) in lanolin paste and of Strawborry Norman by spraying with gibberellic acid at 400 p.p.m. at the pink stage of blossoming; but as his Cox's Orange fruits produced with lanolin paste were only half the size of the seeded fruits, it was thought that an estimation of the cell numbers of such fruits might give an indication of the effectiveness of gibberellic acid in bringing about cell division and provide an explanation for the size differences in such fruits.

As none of the foregoing varietios was available at this Field Station, Gravenstoin and Jonathan trees were used. Small flowering spurs were covered with 'Glassine' bags in 1961, but those proved unsatisfactory owing to condensation of moisture within tho bags; hence in 1962 blossoms wore not coverod after treatment except for one series of Gravenstein blossoms which romained in bags ovor the blossoming period. At the 'balloon' stage, corresponding to 1-2 days before full bloom, tho petals were cut away, anthors removed and styles decapitated. Gibberellic acid at a concentration of 400 p.p.m. was sprayed with a hand atomizer on to the receptacles in 1961 and again in 1962 with a further sories of Jonathan receptacles sprayed at 800 p.p.m. The de-antherod, blossoms remained uncovored. Fruit set, judged by a definito swelling of the receptacle, was estimated after 14 days in 1961 and after 28 days in 1962. At maturity fruits were gathered, weighed and sized, and sections prepared for estimation of cell size and number after tho methods of Bain and Robertson ${ }^{2}$. The long and short diameters of ' 30 Jonathan fruits from each treatment were measured with calipers to detormine any change in shape of fruit.

A summary of the results obtainod is given in Table 1. The fruit set with gibberollic acid compares favourably with that of open pollinated blossoms and with Jonathan in 1962 is considerably highor; a seasonal effect in fruit set may also be present. The Gravenstein fruits produced. with gibberellic acid showed swollen areas at the calyx end in many instances and to this extent were differont from normal fruits. In othor respects as regards maturity, weight and cell number they were similar to the fruits produced by open pollination.

With Jonathan, however, the gibberellic-acid produced fruits wore appreciably smaller, of less mean woight and with a corresponding lesser number of cells; the ratio of fruit-length to diameter indicated that these fruits were relativoly elongated, the ratios for normal fruits being 0.84 as compared with 0.89 for gibberellic-acid produced fruits. Moreover, these fruits were less symmetrical than normal, showing a raisod shoulder on ono side in many cases. No seeds were found in gibberellic-acid treated fruits.

As cell volume appears to be similar within treatments for both varioties of apple, it is suggested that the diffor- ence in woight of the gibberellic-acid produced Jonathan fruits is due to the failuro of tho gibberellic acid stimulus to bring about the requirod number of eell divisions to produce full-sized apples, at the concentration used. The gibberellic-acid produced Jonathans are 79.9 per cent the weight of the open pollinated fruits, and approximately the same proportion of cells, namely, 81.7 per cent, were produced in these fruits as compared with seeded fruits.

\section{A. Thomas}

Division of Plant Industry, C.S.I.R.O.,

Field Station,

Applethorpe, Queensland.

' Davison, R. M., Nature, 188, 681 (1960).

¿ Bain, Joan M., and Robertson, R. N., Austral. J. Sci. Res., B, 4, 75 (1051).

\section{Therapeutic Activity of a Streptothricin-like Antibiotic against Apple Mildew}

THe streptothricin-]ike antibiotic complex, reference number $A 4788$, isolated and characterized by Lumb et al. ${ }^{1}$ has high in vivo activity against a number of powdery mildow diseases including Podosphaera leucotricha on apple. Preliminary tosts indicated that the mode of action of the antibiotic was essentially different from that of oither dinocap or sulphur and investigations into the chemotherapentic effects of the material wero therefore undertaken.

$M M .106$ apple root-stocks were uniformly infected with mildew in an inoculation tower similar to that dogcribed by Kirby and Frick ${ }^{2}$, and disease rating was estimated with the aid of matching diagrams as tho mean percentage of the adaxial leaf surface area infected by apple mildew on the first five to seven fully expanded leaves of an extension shoot. Different treatments were replicated on at loast five plants and assessments repeated two or threo times at 5-7-day intervals. Spraying infocted root-stocks with aqueous sprays containing 0.02 and 0.01 per cent $A 4788$ caused a reduction within a week of more than 80 per cent in the level of mildew compared with that on control plants receiving water sprays, but the maximum effect was not reached until a fortnight after the spraying date when a reduction of 95 per cent was rocorded. On root. stocks, inoculated less than one day after spraying with concentrations of $A 4788$ in the range 0.01-0.08 per cent, protection increasod with concentration, but when an ethoxylated octylphenol wetting agent was added, the degree of control at 0.01 per cent was of the same order as that obtained at 0.08 per cent without wotter (more than 90 per cent). Protectant activity declined as the interval between sprøying and inoculation was incroased although some measure of control was maintained when inoculation was delayed up to 11 days after spraying.

Gray $^{3}$ has shown that streptothricin, applied to intormediate leaves of bean and tobacco plants at a concentration of 1 per cent, is translocated in high amounts both

Table 1

\begin{tabular}{|c|c|c|c|c|c|c|c|}
\hline Variety & Treatment & $\begin{array}{c}\text { No. blossoms } \\
\text { t,reated }\end{array}$ & $\begin{array}{l}\text { Per cent } \\
\text { set }\end{array}$ & $\begin{array}{l}\text { No. fruits } \\
\text { in sample }\end{array}$ & $\begin{array}{l}\text { Mean fresh } \\
\text { wt. (g) }\end{array}$ & $\begin{array}{l}\text { Mean cell } \\
\text { vol. }\left(\mathrm{mm}^{3}\right)\end{array}$ & $\begin{array}{c}\text { Mean cell } \\
\text { No. (millions) }\end{array}$ \\
\hline $\begin{array}{l}\text { Gravenstein } 1961 \\
\text { Gravenstein } 1962\end{array}$ & $\begin{array}{l}\text { GA at } 400 \text { p.p.m. } \\
\text { Open-pollinated } \\
\text { GA at } 400 \text { p.p.m. } \\
\text { Open-pollinated } \\
\text { Control } \\
\text { de-anthered } \\
\text { Bagged entire } \\
\text { blossom } \\
\text { GA at } 400 \text { p.p.m. } \\
\text { Open-pollinated } \\
\text { CA at } 400 \text { p.p.m. } \\
\text { GA at } 400 \text { p.p.m. } \\
\text { Control } \\
\text { de-anthered } \\
\text { Open-wollinated }\end{array}$ & $\begin{array}{l}300 \\
300 \\
100 \\
100 \\
100 \\
100 \\
185 \\
185 \\
100 \\
100 \\
100 \\
100\end{array}$ & $\begin{array}{r}29 \cdot 6 \\
34 \cdot 3 \\
39 \cdot 0 \\
48 \cdot 0 \\
0 \cdot 0 \\
0.0 \\
42 \cdot 0 \\
37 \cdot 2 \\
79 \cdot 0 \\
03 \cdot 0 \\
2 \cdot 0 \\
68 \cdot 0\end{array}$ & $\begin{array}{l}13 \\
15\end{array}$ & $\begin{array}{l}138 \cdot 0 \\
131 \cdot 5\end{array}$ & $\begin{array}{l}0.0055 \\
0.0056\end{array}$ & $\begin{array}{l}22 \cdot 5 \\
21 \cdot 1\end{array}$ \\
\hline
\end{tabular}

